\title{
TRAINING OF OFFICERS OF THE NAVAL FORCES OF UKRAINE IN HIGHER MILITARY EDUCATION INSTITUTIONS: PRESENT AND PROSPECTS
}

\author{
Ruslan Shevchenko \\ Candidate of Military Sciences, Senior Lecturer at the Department of Tactics \\ and General Military Disciplines, Naval Institute National University \\ "Odesa Maritime Academy", Ukraine \\ e-mail: ivanonifrich@gmail.com,orcid.org/0000-0002-1554-2019
}

\section{Summary}

The purpose of the article is to outline the features of the educational process at the Institute of Naval Forces, taking into account the main principles of the Navy Sailor Program 2035 professionalism and competence. One of the main tasks of the program realization of the Strategy of the Naval Forces of the Armed Forces of Ukraine 2035 concerning the development of the personnel "Navy sailor 2035" (professionalism and competence) is the modernization of the education system, which includes three components: the system of candidates selection who enter the Institute of Naval Forces; educational activity; creating a campus of a new type. The Strategy of the Naval Forces of the Armed Forces of Ukraine 2035 outlines their development in three components: conceptual, physical and moral. The principles of compatibility training of officers of the Armed Forces of Ukraine with NATO standards are relevant. Components of NATO's leading DOTMLPF methodology are being embedded in the modern educational process of the future Naval officers' training.

The Institute of the Naval Forces provides a thorough training of tactical level officers in 3 specialties with relevant specializations, which are constantly updating as a result of three staged transition of the Ukrainian Naval Forces to NATO standards. The educational activity of the Institute is aimed at training highly skilled military specialists for the needs of the Naval Forces of Ukraine, able to perform military management of tactical units, organize the tasks of units and take personal and professional responsibility for their actions.

Keywords: officers of the tactical level, the Armed Forces of Ukraine, Navy Sailor Program, higher military education in Ukraine, NATO's basic principles and values

\section{DOI: https://doi.org/10.23856/3827}

\section{Introduction}

In the context of constant military operations in the east of the country (since 2014), the mission of the Armed Forces of Ukraine is constantly changing, ensuring the "deterrence and resistance to armed aggression against Ukraine, protection of the airspace of the state and underwater space within the territorial sea of Ukraine in cases determined by the law, take part in measures aimed at combating terrorism" (Ukrainian Military Pages) (Ukrainian Military Pages). Training of specialists capable to ensure mentioned above is laid on the establishments of higher military education (with peculiar conditions of the educational process organization). In particular, the training of specialists for the Ukrainian Naval Forces is carried out by the only establishment in the country - the Institute of Naval Forces of National University "Odessa Maritime Academy". The particular characteristic of the Institute's activity is the structure of the educational process based on the step-by-step professional military specialists' 
training, training of tactical level officers, and orientation to NATO standards. As the purpose of the "Naval Forces of the Armed Forces of Ukraine is the deterrence of aggression, protection of sovereignty and territorial integrity of Ukraine, ensuring maritime security, economic growth, and international stability, in cooperation with national defense and security forces, strategic partners, on the sea and from the sea direction" (Navy Strategy of the Armed Forces of Ukraine 2035).

One of the main tasks of the program realization of the Strategy of the Naval Forces of the Armed Forces of Ukraine 2035 concerning the development of the personnel "Navy sailor 2035" (professionalism and competence) is the modernization of the education system, which includes three components: the system of candidates' selection who enter the Institute of Naval Forces; educational activity; creating a campus of a new type. These should influence the formation of future tactical level officers' professional competence as "an indicator of the level of a military officer's training capable to perform their duties in a specific position with high quality and efficiency", which includes the following components: strategic thinking, influence, decision-making, analysis of information, focusing on the task, flexibility, focusing on the quality (Sailor Program - 2035 Professionalism and Competence (PIC)).

Considering mentioned above, the purpose of the article is to outline the features of the educational process at the Institute of Naval Forces, taking into account the main principles of the Navy Sailor Program - 2035 professionalism and competence. Its separate tasks are as follows: 1) to characterize the main positions of 2019-2020 on the realization of the educational process at establishments of higher military education in Ukraine; 2) to outline the peculiar features of the restructuring of the educational process at the Institute of Naval Forces.

The basic principles of the theory of cognition and information, resource, and professional approaches represent the methodological basis of the article. A set of methods substantiating the main principles was used: theoretical - general scientific (for substantiating the initial theoretical positions), specific-scientific: structural (to identify and outline the features of educational activity of cadets of relevant specialties) and problem-thematic (to determine real and future opportunities); empirical - content analysis (to identify a set of professional competences of future navy sailors).

\section{Regulating positions on the implementation of the educational process at establishments of higher military education in Ukraine}

The Strategy of the Naval Forces of the Armed Forces of Ukraine 2035 outlines their development in three components: conceptual (offers a thinking structure, intellectual basis for troops, provides commanders with the ability to understand the situation in difficult conditions with the help of creativity, ingenuity, and initiative), physical (means of conducting armed struggle: military personnel, armament and military equipment, unit cohesion, combat readiness and logistics/comprehensive provision) and moral (based on the legitimacy of troops, ethical principles, enthusiasm and readiness to fight, encouraging the offensive spirit, initiative and determination to fulfill a combat mission) (Navy Strategy of the Armed Forces of Ukraine 2035). The activity of higher military educational establishments as for the training of naval officers has to be directed exactly on their formation and further development.

In this context, the principles of compatibility training of officers of the Armed Forces of Ukraine with NATO standards are relevant, as both physical and conceptual components are possible "only due to mastering NATO's principles, standards and values in education, training 
and use of the Naval Forces of the Armed Forces of Ukraine" (Navy Strategy of the Armed Forces of Ukraine 2035), and Ukraine is a country of "Accelerated dialogue" partnership.

The legal and regulatory framework of educational activity of higher military education establishments has been updated, in particular, at the beginning of 2020, the Regulation on the peculiarities of the educational activity organization at higher military educational establishments of the Ministry of Defense of Ukraine and in military training units of higher education establishments was adopted and ratified (Decree of the Ministry of Defense of Ukraine, 09.01.2020 № 4). Emphasis is placed on the candidates' competencies acquisition in humanitarian, social, scientific and natural, technical and military spheres, which is of significant importance for professional activity, and intellectual, moral, spiritual, aesthetic and physical development (Regulations on the peculiarities of the organization of educational activities in higher military educational institutions of the Ministry of Defense of Ukraine and military educational subdivisions of higher education institutions, Section I, paragraph 5) (MDU Order of 09.01.2020 № 42). Mentioned above correlates with the components of The Strategy of the Naval Forces of the Armed Forces of Ukraine as for their development and signifies certain actions ensuring the compatibility of military offices' training.

In the context of NATO's basic principles and values, the Regulation declares that the content of higher military education is determined by the "goals and needs of society, the state and the Armed Forces of Ukraine" and has to be formed considering the priorities of national interests and national security; national interests in the information sphere, development of the system of strategic communications of the national security and defense sector of Ukraine; changes in the economy, politics, social relations, and public consciousness; the latest achievements in science, technology, and culture, providing a military specialist's broad outlook; prospects for the development of military science, armaments, and military equipment, methods of conducting an armed struggle" (Regulations on the peculiarities of the organization of educational activities in higher military educational institutions of the Ministry of Defense of Ukraine and military educational subdivisions of higher education institutions, Section I, paragraph 8) (MDU Order of 09.01.2020 № 4).

Along with the standards of higher education for the training of highly qualified officers capable of effective professional performance, a special practice-oriented in meaning and content place occupy professional standards as the "requirements for the military specialist's competencies, which are the basis for professional qualifications" and are developed by "the body of military administration, that is a customer for the military specialists' training with the participation of representatives" of the higher military educational establishment with the appropriate agreement and approvement (Regulations on the peculiarities of the organization of educational activities in higher military educational institutions of the Ministry of Defense of Ukraine and military educational subdivisions of higher education institutions, Section I, paragraph 10) (MDU Order of 09.01.2020 № 4).

The Institute of the Naval Forces of National University "Odessa Maritime Academy" provides a thorough training of tactical level officers in specialties "Provision of Troops (forces)", "Armament and Military Equipment", "Transport" with relevant specializations, which are constantly updating as a result of three staged transition of the Ukrainian Naval Forces to NATO standards. Peculiarities of the training of Master's Degree students - the officers of the Naval Forces are outlined in the previous author's works, therefore we emphasize the competences which are cross-cutting for obtaining a Bachelor's degree and a Master's degree. These are, in particular, professional and military and professional competencies: the ability to organize personal service activity and the activity of the unit in accordance with 
the statutory requirements; ability to use legal arrangements properly in solving official and professional tasks; ability to manage military personnel; ability to ensure compliance with the safety requirements when solving professional assignments; ability to make informed management decisions when the unit performs set tasks; ability to manage day-to-day operations of units following the requirements of management documents; ability to control the actions of a general military platoon while performing the main set tasks; ability to organize the protection of the unit from weapons of mass destruction; ability to provide management and negotiate through means of communication; ability to properly organize and implement measures to combat the survivability of the surface ship; physical readiness to perform set tasks; ability to ensure the preservation of state secrets; ability to communicate in English in the social and professional spheres (we note that the article contains information that is not a state secret and is taken from the open sources).

Mentioned above interacts with one of the components of NATO's leading DOTMLPF methodology, which includes a doctrinal base $(\mathrm{D})$, organization $(\mathrm{O})$, training $(\mathrm{T})$, resource provision $(\mathrm{M})$, leadership and education $(\mathrm{L})$, personnel $(\mathrm{P})$, and military infrastructure (F), providing the establishment of new staff structures on adaptation and implementation of NATO's standards, principles, and values (Navy Strategy of the Armed Forces of Ukraine 2035).

\section{Features of the educational process organization at the Institute of Naval Forces}

The Regulation adjusts the organization and provision of educational activity; organization of the educational process at establishments of higher military education and structural subunits; training and advanced training of management and academic staff; other activities (Regulations on the peculiarities of the organization of educational activities in higher military educational institutions of the Ministry of Defense of Ukraine and military educational subdivisions of higher education institutions) (MDU Order of 09.01.2020 № 4).

The Institute of the Naval Forces of National University "Odessa Maritime Academy" is governed by The Regulation on the organization of the educational process, developed in accordance with the Constitution of Ukraine, laws of Ukraine in the field of education, regulations of the Ministry of Education and Science of Ukraine, the Ministry of Defense of Ukraine, the Statute of National University "Odessa Maritime Academy" (further - the University), the Regulation on the Institute of the Naval Forces of National University "Odessa Maritime Academy" (further - the Institute), as well as taking into account the requirements of the General Staff of the Armed Forces of Ukraine, the Command of the Naval Forces of the Armed Forces of Ukraine, features, and experience of educational activity at higher military educational establishments of the Armed Forces of Ukraine (Regulations on the organization of the educational process at the Institute of Naval Forces of the National University "Odessa Maritime Academy"). According to the Regulation, the educational activity of the Institute is aimed at "training highly skilled military specialists for the needs of the Naval Forces of the Armed Forces of Ukraine, able to perform military management of tactical units, organize the tasks of units and take personal and professional responsibility for their actions" (Regulations on the organization of the educational process at the Institute of Naval Forces of the National University “Odessa Maritime Academy”).

Among the main tasks of the educational activity of the Institute are "candidates' achievement of the competencies defined in the educational programs and professional standards of the military specialists' training; introduction of the combat experience of troops (forces) in the educational process; improvement the quality of information and methodological support 
of the educational process through the development and publication of textbooks and manuals, collection of lectures and practical tasks; improvement the quality of the material and technical support of the educational process by creating computer classes with specialized mathematical software; improvement the maritime cadets' training by their participation in a boat and motorboat trips, involvement in combat training of the Naval Forces of the Armed Forces of Ukraine, conducting practical classes and training on ships (vessels); study of the standardized NATO naval tactical procedures, improvement of the language training level and practical skills of cadets in methodological, military-professional and military-special training by ensuring full and high-quality implementation of measures for improving practical training of cadets" (Regulations on the organization of the educational process at the Institute of Naval Forces of the National University “Odessa Maritime Academy”), aimed at implementing NATO's leading DOTMLPF methodology.

Cadets are trained on a full-time basis according to the educational programs of a Bachelor's degree and a Master's degree in specialties "Provision of Troops (forces)", "Weapons and Military Equipment", "Transport" and by correspondence without interruption of their official duties within the retraining and advanced training program of military officers of the Armed Forces of Ukraine.

Consequently, the implementation of the educational process at the Institute of Naval Forces is regulated by its points. We focus only on the main organizational forms of the educational activity: academic classes (compulsory types: a lecture, a seminar, a group class, a practical class, a laboratory class, a group exercise, a training, an individual task, a tactical (special-tactical, combat-tactical) class, and training, command post exercises and military classes (military-special, military-historical) games, consultation); self-study work; practical training (initial military-professional training; academic, military, repairing, ship, medical, pedagogical, scientific and other types of practices; military naval internship); check measures (Regulations on the peculiarities of the organization of educational activities in higher military educational institutions of the Ministry of Defense of Ukraine and military educational subdivisions of higher education institutions) (MDU Order of 09.01.2020 № 4) and training (Regulations on the organization of the educational process at the Institute of Naval Forces of the National University “Odessa Maritime Academy”).

According to the Regulation on the organization of the educational process at the Naval Institute, training is the most important type of cadets' practical preparation, carried out on simulators and military equipment, on the ground or in the specially equipped training fields, classrooms aimed at improving and maintaining the necessary skills of cadets concerning armaments and military equipment usage, the organization of unit management (Regulations on the organization of the educational process at the Institute of Naval Forces of the National University “Odessa Maritime Academy”). Training in special (technical) preparation, training in unit management in combat, fire training, training in compliance with standards for protection against weapons of mass destruction, training in compliance with standards in military topography, training in compliance with standards in technical preparation is required. This significantly improves the quality of military training, as it is of a completely military-specialized character, along with the command and staff training, war games and military training - aimed at acquiring and improving knowledge, skills and practical skills in performing duties of the relevant position in the army (forces) and is carried out in military units (on ships, at institutions, at establishments) (Regulations on the organization of the educational process at the Institute of Naval Forces of the National University "Odessa Maritime Academy”). 


\section{Conclusions}

In accordance with the set purpose and defined tasks, the conclusions are as follows: the educational process of the Naval officers' training at the Naval Institute is based on the basic principles of the Strategy of the Naval Forces of the Armed Forces of Ukraine 2035, the Navy Sailor Program - 2035 professionalism and competence, the Regulation on the peculiarities of the educational activity organization at higher military educational establishments of the Ministry of Defense of Ukraine and in military educational units of higher educational establishments (Decree of the Ministry of Defense of Ukraine, 09.01.2020 № 4), The Regulation on the organization of the educational process at the Institute of Naval Forces of the National University "Odessa Naval Academy" and others, which became the basis for their making; higher education standards and educational and professional standards. Components of NATO's leading DOTMLPF methodology are being embedded in the modern educational process of the future Naval officers' training. A significant aspect of increasing the level of cadets' military professional preparation is training and military internships, as they contribute to the improvement of cadets' skills acquired during the training.

Prospects for improving the educational process at the Institute of the Naval Forces are as follows: increasing the level of professionalism of the teaching staff by involving combat officers and strengthening of the scientific component of the current teaching staff; improving the system of professional cadets selection and providing conditions for their professional development; improving the material and technical base to provide opportunities for internships in terms of real technical equipment of the Ukrainian Naval Forces; strengthening of cooperation with higher educational establishments of NATO member countries on the implementation of the main provisions of the NATO's DOTMLPF methodology.

\section{References}

Polozhennya pro orhanizatsiyu osvitnoho protsesu v Instytuti Viyskovo-Morskykh Syl Natsional'noho universytetu "Odeska morska akademiya" [Regulations on the organization of the educational process at the Institute of Naval Forces of the National University "Odessa Maritime Academy”]. URL: http://fvms.onma.edu.иа/Положення\%20про\%20організаиію\%20 освітнього\%20проиесу\%20Iнституту\%20BMC.pdf [in Ukrainian].

Polozhennya pro osoblyvosti orhanizatsiyi osvitnioyi diyal'nosti u vyshchykh viyskovykh navchalnykh zakladakh Ministerstva oborony Ukrayiny ta viyskovykh navchalnykh pidrozdilakh zakladiv vyshchoyi osvity (Nakaz MOU vid 09.01.2020 № 4) [Regulations on the peculiarities of the organization of educational activities in higher military educational institutions of the Ministry of Defense of Ukraine and military educational subdivisions of higher education institutions (MDU Order of 09.01.2020 № 4)] URL: https://www.mil.gov.ua/ministry/normativno-pravova-baza/nakazi-ministra-oboroni-ukraini/nakazi-ministerstva-oboroni-ukraini-za-2020-rik.html [in Ukrainian].

Prohrama Viyskovy moryak - 2035 profesiynist' $i$ kompetentnist' (PiK) [Sailor Program - 2035 Professionalism and Competence (PIC)]. URL: https://navy.mil.gov.ua/prezentatsiya-programy-vijskovyj-moryak-2035/ [in Ukrainian].

Stratehiya Viyskovo-Morskykh Syl Zbroynykh Syl Ukrayini 2035 [Navy Strategy of the Armed Forces of Ukraine 2035]. URL: https://navy.mil.gov.ua/strategiya-vijskovo-morskyh-syl-zbrojnyh-syl-ukrayiny-2035/[in Ukrainian].

Ukrainian Military Pages. URL: https://www.ukrmilitary.com/p/armed-forces-of-ukraine.html 